\title{
A Two-Degree-of-Freedom of Motion Mechanical Oscillatory System with Excitation and Limit Cycle Oscillation - Automatic Armament Case
}

\author{
Zdravko Banjac ${ }^{1)}$ \\ Snežana Jovanović ${ }^{2)}$
}

\begin{abstract}
This paper presents a numerical analysis of motion dynamics of a two-degree-of-freedom of motion rectilinear oscillatory system with the motion limitations and forced excitation. The analysis of a mechanical-mathematical model with discontinued parameters is based on the numerical integration of differential equations. The forced oscillatory system has been implemented in two automatic armament systems of $12.7 \mathrm{~mm}$ and $20 \mathrm{~mm}$ calibres, which have been installed in the light propeller aircraft and transport-combat helicopter. The motion parameters - movement and velocity and forces have been measured on the stand. Motion parameters and force computations were compliant with the analogous values measured on the designed systems. The mechanical-mathematical model of system dynamics can be used for a prediction of the behaviour of a two-degree-of-freedom of the motion system in the stage of parameters adjustment, prior to the design of system elements. The description of the measurement and used equipment is presented as well as a possible way of further work
\end{abstract}

Key words: mechanical system, oscillatory system, oscillatory moving, self-oscillating, eigen frequency, system excitation, forced oscillations, oscillation damping, automatic weapon, $12.7 \mathrm{~mm}$ calibre, $20 \mathrm{~mm}$ calibre, aircraft armament.

\section{Introduction}

$I^{N}$ $\mathrm{N}$ the design of automatic weapons installation into aircraft, one of the main parameters is the force that is transmitted from the weapon to the surrounding structure. This force is an important factor, not only for the dimensioning of the surrounding structure but also for the behaviour of other system elements close to the weapon, i.e. equipment etc. Depending on the sensitivity of the surrounding structure and the equipment, the requirement for reducing the weapon impact, as an excitation, on other system components will be set.

In one-degree-of-freedom of motion systems the weapon has an internal elastic system and the external elastic system for weapon connection to the supporting structure. A common denominator for various variants of one-degree-of-freedom systems is that the reduction domain of the force transmitted from the weapon to the structure is restricted [1]. This is conditioned mainly by limited weapon recoil (in the opposite direction of the projectile movement) due to the problem of feeding the ammunition to the weapon. The main system parameters here are the rate of fire, i.e. excitation frequency and self-oscillating frequency of the weapon. The effect of weapon movement on its internal work is hard to anticipate, so it is mainly reduced to recoil adjustment and correction of the parameters of the designed system.

In cases where the requirement for reduction of the force transmitted from the weapon to the supporting structure is extremely harsh, a two-degree-of-freedom of motion system is used, i.e. the weapon whose primary supporting structure moves with respect to the remaining, immobile, part of the system. This applies predominantly to the pod-type installation of the weapon, especially with light aircraft where the wing structure or the airframe is lightweight and sensitive to the weapon reaction force. An executed example of such a system is Uni-Gun Pod, by Swedish FFV, where a $12.7 \mathrm{~mm}$ machine gun is mounted in a light aircraft pod. In this case, the movement of the entire pod absorbs the weapon recoil force, i.e. the mass collision (of the weapon and the pod) principle is applied, where the reaction force arises as an internal force, while a smaller force is transmitted to the external (immobile) part of the system, as the result of non-absorbed energy of weapon recoil.

With two-degree-of-freedom of motion systems, the impact on the internal work of the weapon is more complex, so, depending on the sensitivity of the weapon, it is necessary to know the behaviour of the system when choosing a weapon installation concept [2].

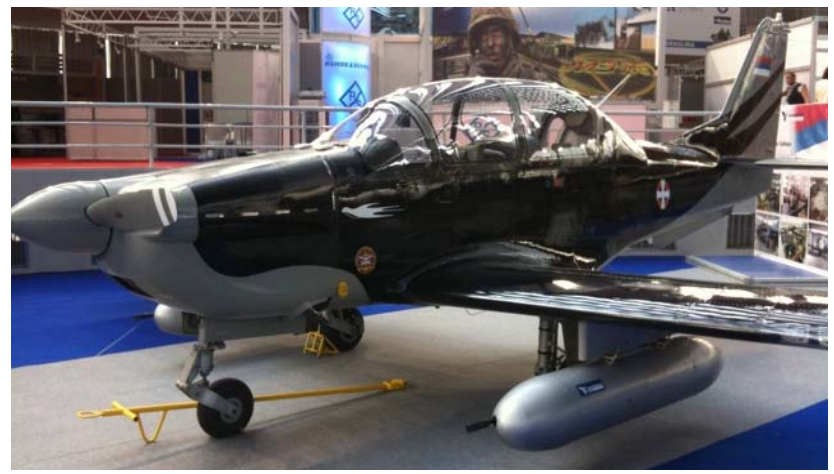

Figure 1. A $12.7 \mathrm{~mm}$ machine gun suspension pod designed for trainercombat aircraft LASTA (SWALLOW)

\footnotetext{
1) Jurija Gagarina 60/62, 11070 New Belgrade, SERBIA

2) Technical Test Cente (TOC), Vojvode Stepe 445, 11000 Belgrade, SERBIA

Correspondence to: Zdravko Banjac; e-mail: zdravkob3@gmail.com
} 
This paper defines the mechanical-mathematical model and uses a numerical model for solving differential equations for a prediction of the behaviour of a two-degree-of-freedom of motion system. The model includes all the relevant parameters: rate of fire, i.e. excitation frequency and force, movement restriction of the weapon and the primary supporting structure, damping, friction, pre-stresses of springs, corresponding spring stiffness, and mass of the system components.

The mechanical-mathematical model has been realized within two projects: suspension pods with (a)-12.7mm machine gun for Lasta aircraft, and (b)-20 mm cannon for Mi17 helicopter [3-5]. Necessary measurements of recoil force transferred to a stand and movement of the pods and guns were done at the time of the ground examination of the pods. The numerical results have shown good compliance with the executed systems with two degrees of freedom for 12.7 and $20 \mathrm{~mm}$ calibres. The addressed parameters include motion (velocity and movement) and force. A prediction for the 30 $\mathrm{mm}$ two-degree-of-freedom of motion system has been made.

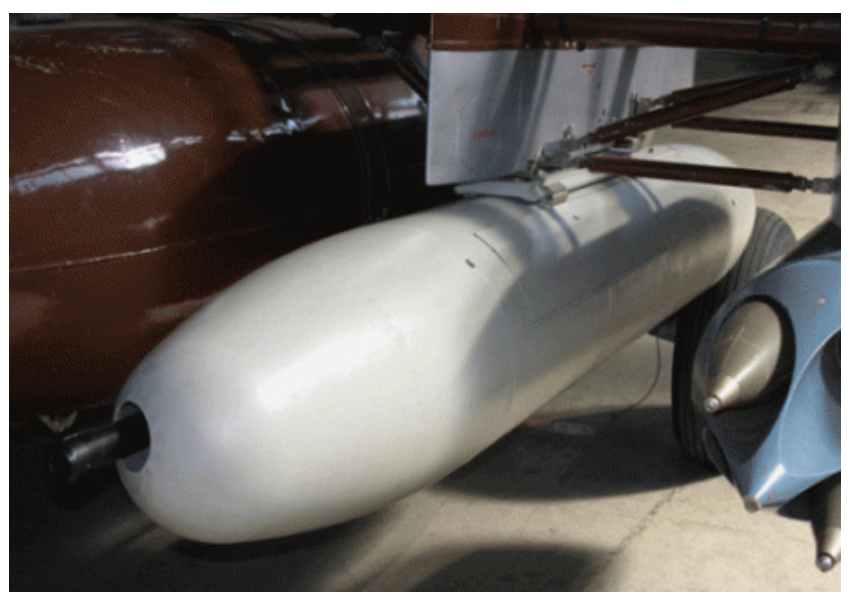

Figure 2. A 20mm automatic canon suspension pod designed for helicopter Mi-17

\section{Mechanical-mathematical model of a two degree- of-freedom of motion system}

A two-degree-of-freedom of motion system and a corresponding mechanical-mathematical model for the system behaviour have been defined and analyzed (Fig.3). Initial conditions (coordinate systems 1 and 2) have been set and the parameters defined.

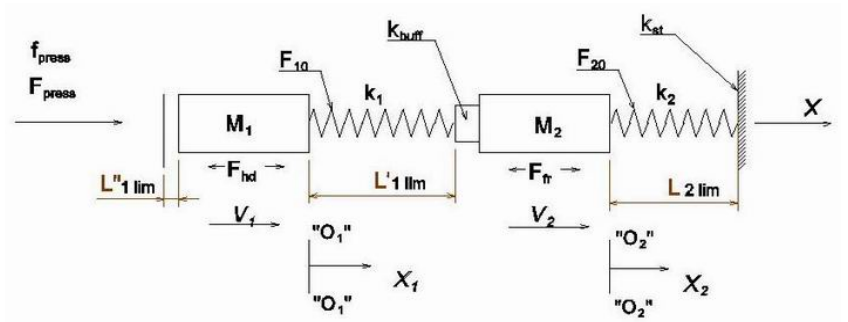

Figure 3. Described mechanical model of a rectilinear two-degree-offreedom of motion oscillatory system

Listed below are the values used in the model and the numerical analysis:

$F_{\text {press }}$ - Pressure force of powder gases in the barrel. It is modeled as a series of rectangles, whose total surface is equal to the surface below the actual pressure curve (Fig.4a) $f_{\text {press }}$ - Frequency of excitation (rate of fire). It is not independent from the system behaviour. It is modeled as a repetition of impulses of the force $F_{\text {press }}$ in the time axis (Fig.4b)

$M_{1} \quad$ - Weapon mass (mobile part)

$M_{2}$ - Mass of the primary supporting structure (mobile part)

$k_{1} \quad$ - Weapon spring stiffness

$k_{2} \quad$ - Mount spring stiffness (primary supporting structure)

$k_{\text {buf }}-$ Weapon buffer spring stiffness

$k_{s t}-$ Base stiffness (immobile supporting structure) at the weapon supporting point

$k_{h d}$ - Hydraulic damping coefficient, different for two directions

$F_{10} \quad$ - Pre-stress of the weapon spring

$F_{20}$ - Pre-stress of the weapon mount spring

$F_{h d}$-Hydraulic damper force, function of the weapon movement speed

$F_{f r}$ - Friction force, function of the weapon mount position

$F_{b u f}$ - Force in the weapon buffer, function of the weapon position and weapon mount position

$F_{s t}$ - Force in the base (immobile structure), function of the weapon mount position

$V_{1} \quad$-Weapon velocity (absolute)

$V_{2}$ - Weapon mount (cradle) velocity with respect to the immobile structure

$L_{1 \text { lim }}^{\prime}$ - Restriction of the weapon movement in the positive direction (Fig.3)

$L_{\text {lim }}^{\prime \prime}$ - Restriction of the weapon movement in the negative direction (Fig. 3)

$L_{2 \lim }$ - Restriction of the mount movement in the positive direction (Fig.3)

$X_{1} \quad$ - Weapon movement (absolute)

$X_{2}$ - Weapon mount movement (absolute)

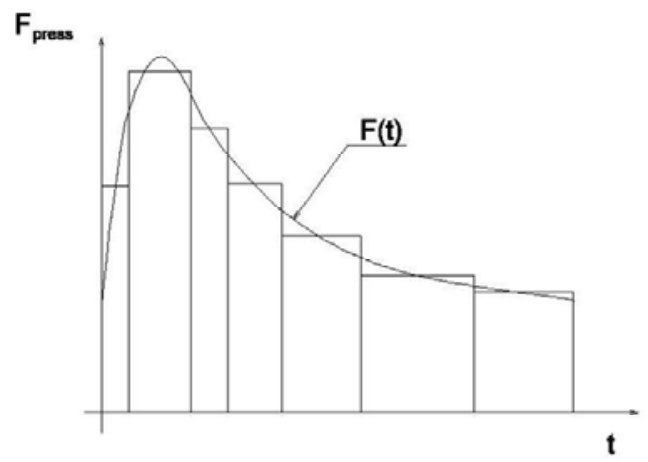

a)

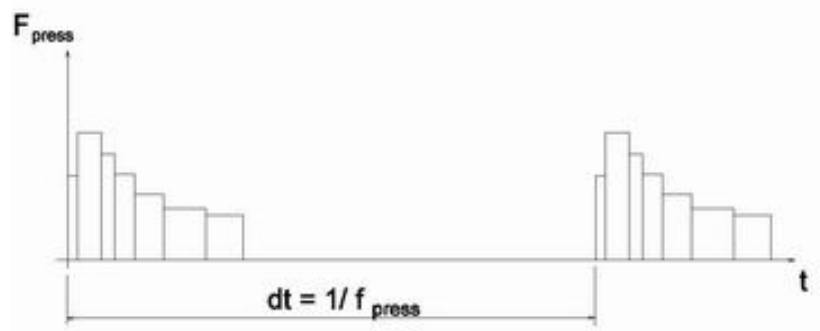

b)

Figure 4. Model of excitation force (a) and force distribution in time (b)

The described model does not include the reduced mass of the immobile supporting structure. 


\section{Motion equations}

The beginning of the coordinate system adopted for the weapon movement $\left(M_{1}\right.$ in Fig. 3$)$ is the initial position and the positive direction of $x$-axis in the direction of the weapon recoil. The coordinate system adopted for the mount movement has the beginning in the initial position of the mount and the positive direction in the direction of the weapon recoil. Motion has been determined by using 4 linear first-degree differential equations with constant coefficients, coupled based on $V$ and $X$ parameters.

$$
\begin{gathered}
\frac{d V_{1}}{d t}=\frac{F_{\text {press }}-k_{1}\left(X_{1}-X_{2}\right)-F_{b u f f}-F_{10}-F_{h d}}{M_{1}} \\
\frac{d X_{1}}{d t}=V_{1} \\
\frac{d V_{2}}{d t}=\frac{k_{1}\left(X_{1}-X_{2}\right)+F_{b u f f}+F_{10}-F_{h d}-k_{2} X_{2}-F_{s t}-F_{20}-F_{f r}}{M_{2}} \\
\frac{d X_{2}}{d t}=V_{2}
\end{gathered}
$$

where:

$$
\begin{gathered}
F_{b u f f}=k_{b u f f}\left(\left(X_{1}-X_{2}\right)-L_{1 \lim }\right) \\
F_{s t}=k_{s t}\left(X_{2}-L_{2 \lim }\right) \\
F_{h d}=-\left(V_{1}-V_{2}\right) k_{h d}
\end{gathered}
$$

The author's computer program for numerical solving of differential equations is based on the fourth-order RungeKutta method, and it has been written in FORTRAN programming language. The nature of very sharp periodic changes of system parameters imposes a small integration step-size in the independent variable (time), so that in each oscillation half-cycle there are at least five points. The parameters are discontinued, which is executed in the program through the limit values of movement ( $L_{1 \text { lim }}^{\prime}, L_{1 \text { lim }}^{\prime \prime}, L_{2 \text { lim }}-$

Fig.3) and, consequently, force. The program includes all the stated parameters and restrictions and initial conditions are: $V_{1}=V_{2}=0, X_{1}=X_{2}=0$.

\section{The results of numerical analysis of the mechanical-mathematical model}

The numerical analysis has included the installation of 12.7 $\mathrm{mm}$ and $20 \mathrm{~mm}$ suspension pods on the aircraft, cases (a) and (b), as well as the installation of a $30 \mathrm{~mm}$ weapon.

The result of the numerical simulation for the first case $(12.7 \mathrm{~mm})$ is shown in Figures 5 and 6. Fig.5a presents the function of a velocity of the weapon (1) and the weapon mount (2). Fig.5b indicates the function of the movement of the weapon (1) and the weapon mount (2). It can be seen in Fig. $5 b$ that the movement of the weapon (1) and the mount (2) is shifted in the phase about 180 degrees, thanking to the effect of excitation that occurs in the phase of the weapon mount moving forward, and is optimal when the velocity $V_{2}$ has maximum value in the forward direction. At the beginning, we have a period of establishing the state that lasts for several fired rounds. After establishing a stable dynamic process, the system remains stable, i.e. it has a good phase attitude. Fig.6a shows the function of the force in the weapon buffer (1) and the force with which the weapon acts on the immobile mount (2). It can be seen that with the first projectile fired, the force is the biggest, while in the subsequent firings in the burst the recoil energy is absorbed in the collision of the weapon and mount masses, so the force acting on the external surroundings (mount) is comparatively small. The process is dynamically well balanced owing to the adequate selection of the weapon mount spring $\left(k_{2}\right)$, which is the key factor in defining a system of this kind. The final $k_{2}$ for each weapon in this analysis was obtained after numerous executions of the program. The influence of $k_{2}$ could be a subject of a particular analysis. Additional adjustments can be made by selecting the right friction and/or damping. In addition, it can be seen that the process is stable, i.e. that the force is not intensified when the burst is longer. From diagrams $5 \mathrm{~b}$ (curve 2) and 6a (curve 2), it can be seen that there is a similarity in the nature of the weapon mount movement (spring deformation) and the force on the mount, which is to be expected with such a system. Direct proportion does not exist due to the friction and nonlinear character of the damping force.

If the diagram of the force acting on the mount (Fig.6a, curve 2 ) is compared with the measured results (Fig.6b), it can be seen that the computed value is compliant with the measured value, both with respect to the amplitude and the phase. Phase attitude is favourable, i.e. the relationship between the movement phases of the weapon and the cradle is about 180 degrees. This is the result of adjusting the self-oscillating frequency of the weapon mount with the excitation frequency (rate of fire). The double pulses of the force in the diagram in Fig.6b are explained by an internal movement of the parts within the weapon (breech), and their impacts on the internal buffer, the force of which is transmitted to the weapon receiver and then on to the cradle and the base (immobile mount). Different force direction in the diagrams in Figures $6 a$ and $6 b$ is the result of the adopted positive direction of the coordinate system axis during the measurements.

Figures 7 and 8 show the results of the numerical analysis for the second case (20mm weapon). The result is similar as in the first case. Fig.7a shows the function of the weapon velocity (1) and mount (2), while Fig. 7b indicates the function of the weapon (1) and mount (2) movement. It is obvious from the diagrams that the phase attitude is favourable. Figure 8 a shows the function of the force in the weapon buffer (1) and the force on the immobile mount (2). It can be seen that the phase attitude is favourable and that the force is not intensified with the length of the burst. In this case, it was found that the function of the kinematics of the weapon system is more sensitive relative to the characteristics of the two-degree-of freedom system. The parameters are selected so as to achieve stable behaviour of the system, i.e. there is no force intensification with the burst length. It is also clear that the compliance with the measured force values (Fig.8b) is good both in the amplitude and the phase, and that the phase attitude is good (about 180 degrees).

The third case ( $30 \mathrm{~mm}$ calibre) is shown in Figures $9 \mathrm{a}, 9 \mathrm{~b}$ and 10. Its behaviour is similar to the previous two cases. The velocity is shown in Diagram 9a, movement in Diagram 9b, and force in Diagram 10. The parameters are adjusted using the principle of force reduction and achieving a favourable phase attitude. It is obvious that the system will be stable. Since the system has not been executed, no real comparisons can be made, so the conclusion is based on the similarity with case (a) and case (b). 


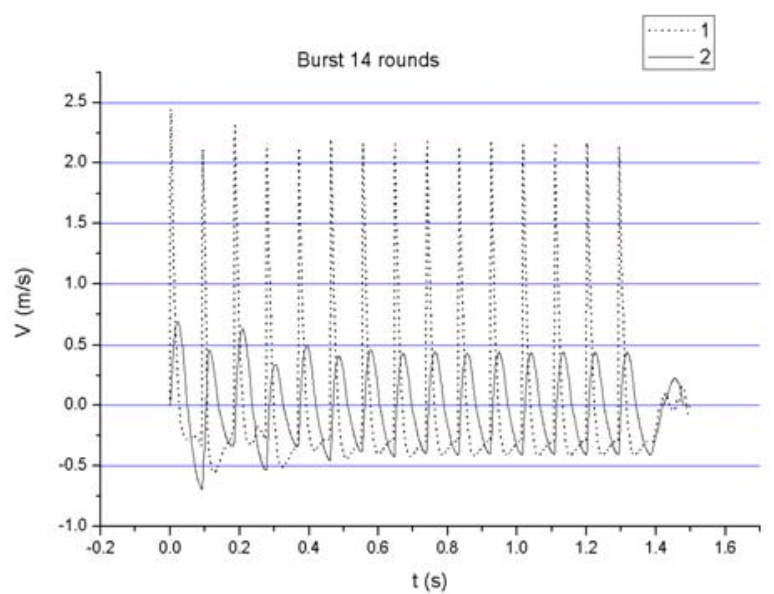

a)

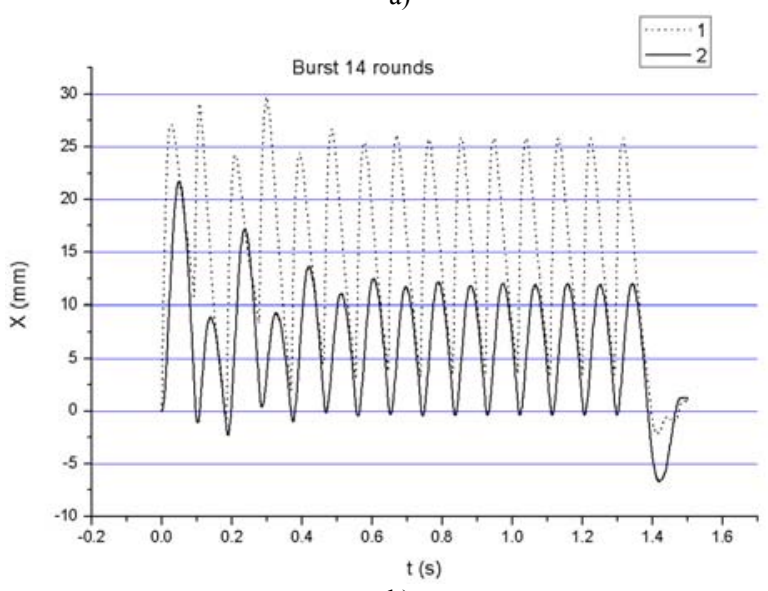

b)

Figure 5. Diagrams of the velocity (a) and movement (b) of the $12.7 \mathrm{~mm}$ weapon and weapon cradle

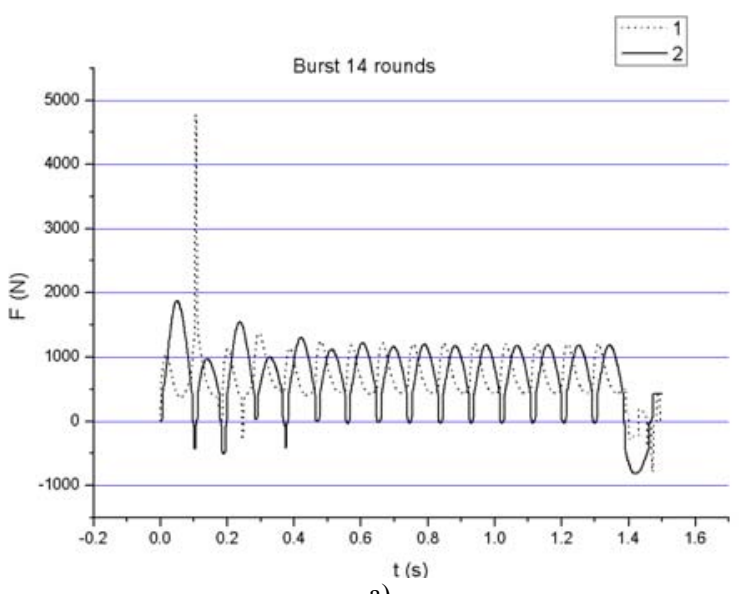

a)

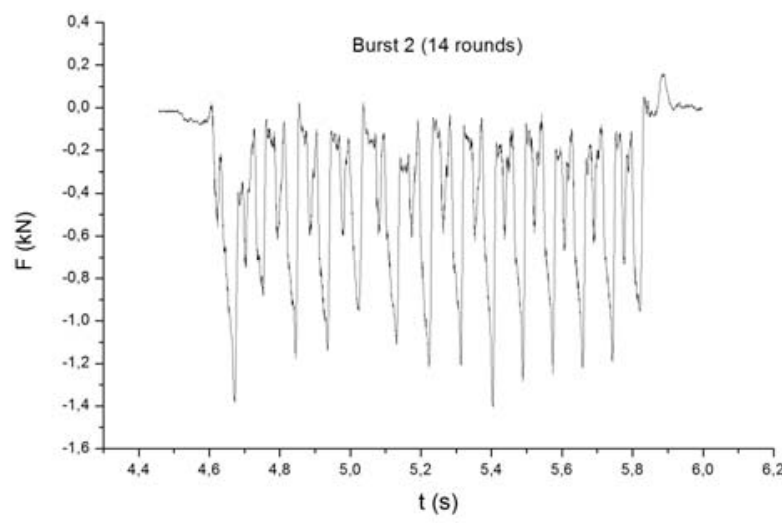

b)

Figure 6. Diagrams of the force acting on the $12.7 \mathrm{~mm}$ gun stand, computed (a) and measured on the executed system (b)

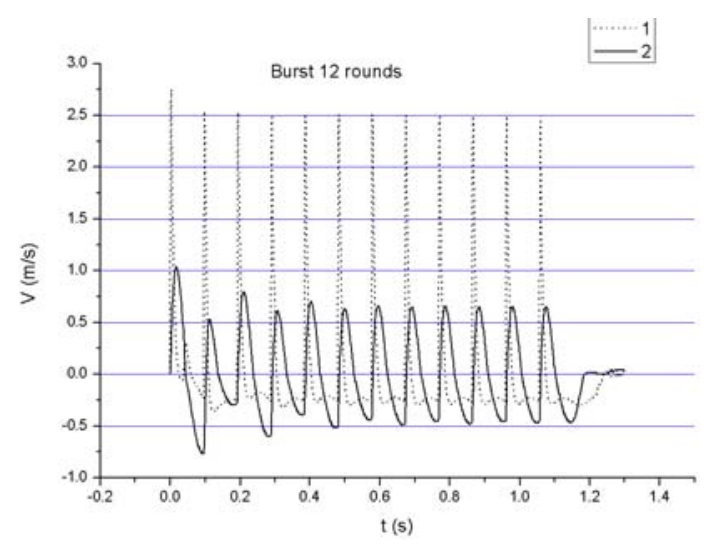

a)

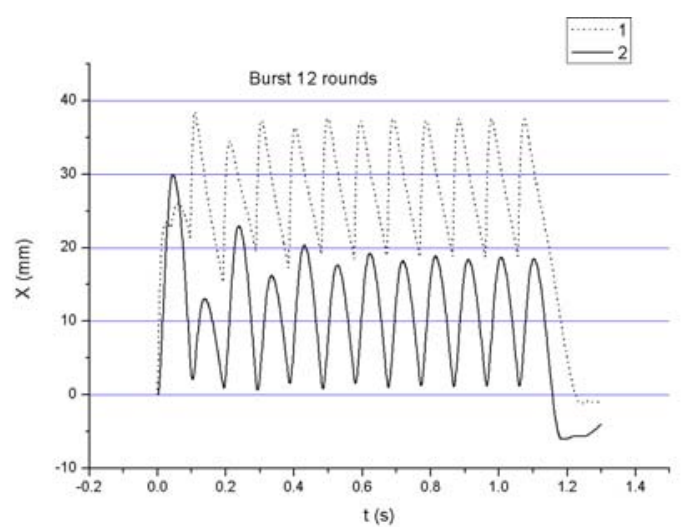

b)

Figure 7. Diagrams of the velocity (a) and movement (b) of the $20 \mathrm{~mm}$ weapon and the weapon cradle

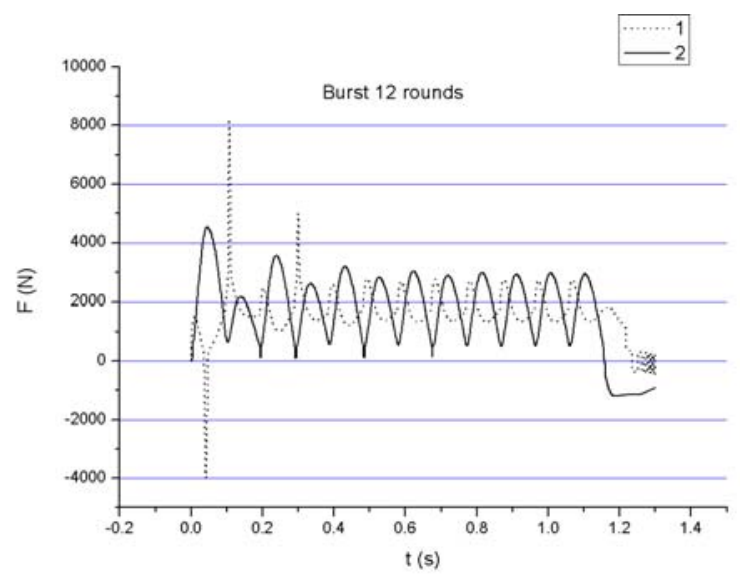

a)

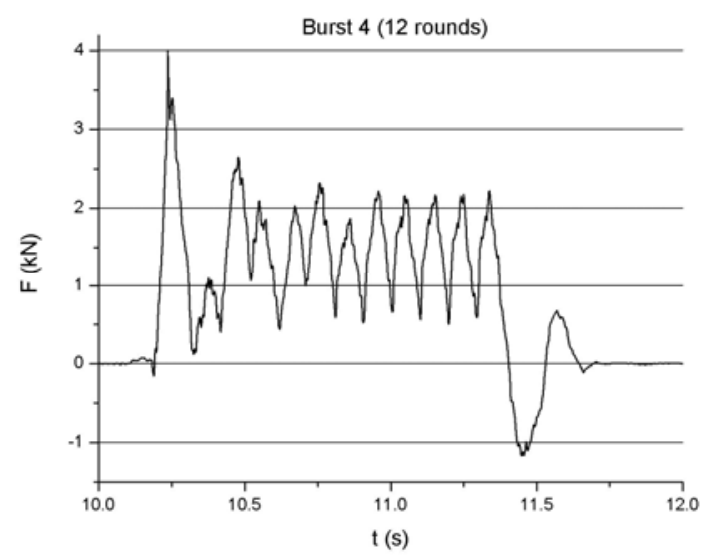

b)

Figure 8. Diagrams of the force acting on the $20 \mathrm{~mm}$ gun stand, computed (a) and measured on the executed system (b) 


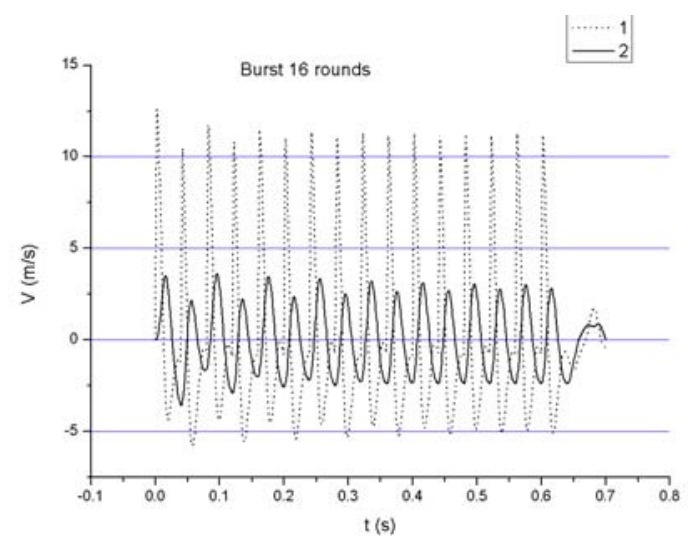

a)

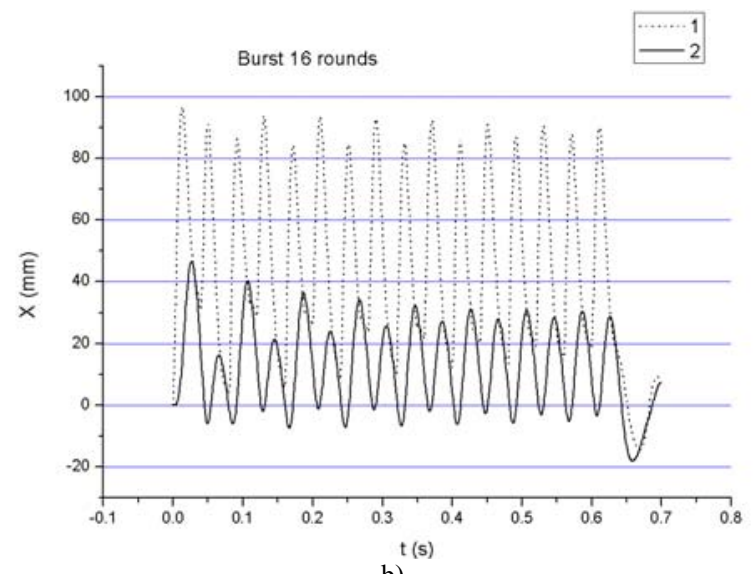

b)

Figure 9. Diagrams of the velocity (a) and movement (b) of the $30 \mathrm{~mm}$ weapon and the weapon cradle

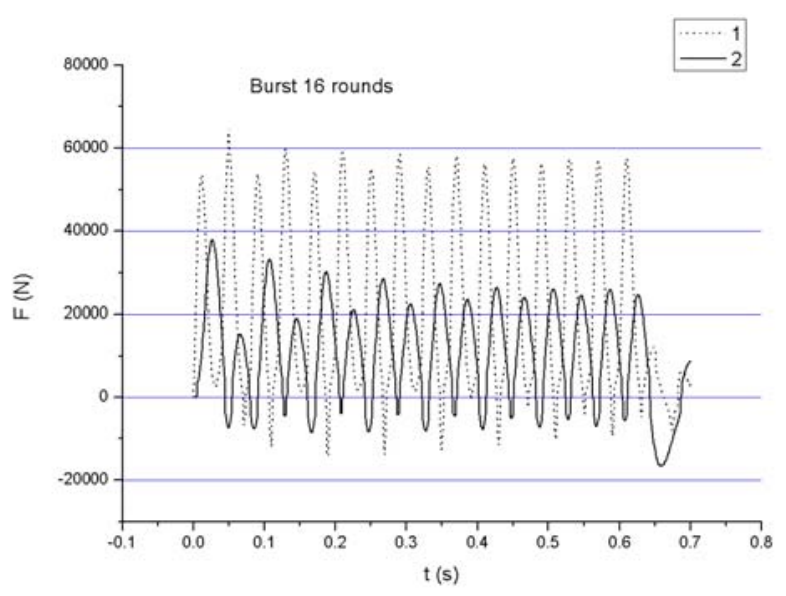

Figure 10. Computational force acting on the 30mm weapon buffer (1) and the force acting on the $30 \mathrm{~mm}$ weapon stand (2)

For all cases, the common feature is that the force acting on the immobile mount is mainly directed backwards, i.e. the force in the opposite direction (forward) is either very small or it does not exist at all. The exception is the last projectile when the process ends. This is very important for the supporting structure, because the force, apart from being reduced, practically varies in one direction, which is a lot better from the aspect of the structure fatigue and vibrations than an alternately variable force. In all cases, the internal force acting on the weapon buffer is observed to be significantly bigger than the external force transmitted from the weapon to the mount, meaning that the objective set by this concept and analysis was actually achieved.

Numerical input values of the program are presented in APPENDIX. Program output values are contained in the numerical data sets for all three weapons (EXCEL and ORIGIN files).

\section{Measuring of force and movement and used equipment}

On the executed $12.7 \mathrm{~mm}$ and $20 \mathrm{~mm}$ pods, the force was measured in both cases [6], while in the case of $20 \mathrm{~mm}$ weapon, the weapon and pod movements were measured as well. For the movement measurements, a linear induction sensor BALLUFF BTL5 with the required length $(100 \mathrm{~mm})$ and velocity range was used.

For the force measurements, a load cell HBM U2B 10kN was used, as well as an acquisition system HBM MGC plus. The motion sensors and load cell were connected as shown in Fig.11.

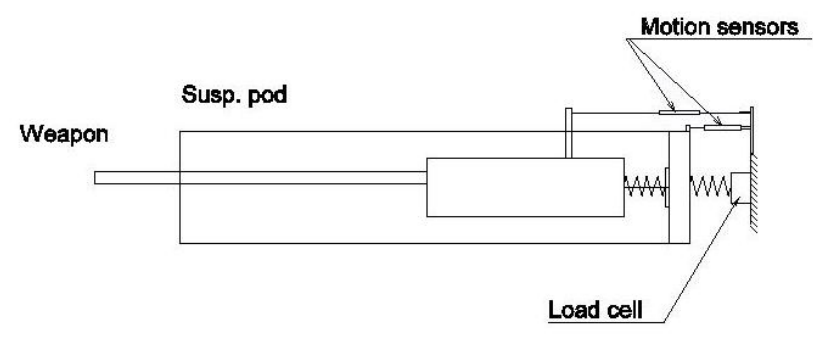

Figure 11. Model of the executed measurement of force and movement

An example of a force measurement in case of the $12.7 \mathrm{~mm}$ weapon is shown in Fig.6b, while an example of the $20 \mathrm{~mm}$ weapon measurement is shown in Fig. 8 b.

In both cases, it can be seen that the computational values are compliant with the measured ones. The parameters are selected so that the weapon mount (cradle) moves within the limits, i.e. there is no collision with the immobile structure, thus preventing the occurrence of a high collision force.

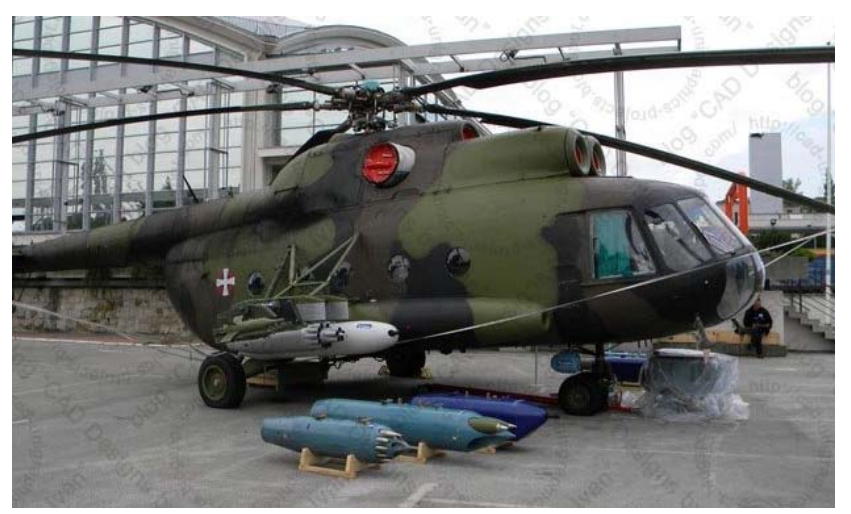

Figure 12. Helicopter Mi-8

\section{Conclusion}

The stated mechanical-mathematical model of a two-degreeof-freedom of motion system with an excitation force has described the system behaviour through parameters: velocity, movement and force. With the adopted approximations, and assuming the system is a linear type, the results of numerical simulation are compliant with the results of measurements on the executed systems. The mechanical-mathematical model, with the author's program, can be very useful in the early project stages of a two-degree-of-freedom of motion system, with respect to choosing the right concept and parameters, and prior to the system components design. The system is implemented within 
two projects: (a)-suspension pod with $12.7 \mathrm{~mm}$ machine gun for the Lasta light aircraft (Fig.1), and (b)-suspension pod with 20mm cannon for the Mi-17 or Mi-8 helicopter (Fig.12).

The mechanical-mathematical model can be extended so as to take into account the internal dynamics of weapon parts, i.e. to describe the actual system through a three-degree-offreedom of motion model.

\section{Appendix}

The list of the program input parameters for the final results in this analysis.

$$
\begin{aligned}
& \text { 12.7mm weapon } \\
& f_{\text {press }}=11.5 \mathrm{~Hz} \\
& F_{\text {press } \max }=32000 \mathrm{~N} \\
& k_{1}=36000 \mathrm{~N} / \mathrm{m} \\
& M_{1}=24 \mathrm{~kg} \\
& k_{2}=70000 \mathrm{~N} / \mathrm{m} \\
& M_{2}=60 \mathrm{~kg} \\
& k_{b u f}=2000000 \mathrm{~N} / \mathrm{m} \\
& k_{s t}=5000000 \mathrm{~N} / \mathrm{m} \\
& F_{10}=400 \mathrm{~N} \\
& F_{20}=350 \mathrm{~N} \\
& L_{1 \lim }^{\prime}=0.028 \mathrm{~m} \\
& L_{1 \lim }^{\prime \prime}=0.001 \mathrm{~m} \\
& L_{2 \lim }=0.05 \mathrm{~m} \\
& k_{h d}=1600 \mathrm{Ns} / \mathrm{m} \\
& F_{f r}=400 \mathrm{~N}
\end{aligned}
$$

$$
\begin{aligned}
& \text { 20mm weapon } \\
& f_{\text {press }}=10.5 \mathrm{~Hz} \\
& F_{\text {press } \max }=81500 \mathrm{~N} \\
& k_{1}=65000 \mathrm{~N} / \mathrm{m} \\
& M_{1}=50 \mathrm{~kg} \\
& k_{2}=140000 \mathrm{~N} / \mathrm{m} \\
& M_{2}=120 \mathrm{~kg} \\
& k_{\text {buf }}=2500000 \mathrm{~N} / \mathrm{m} \\
& k_{s t}=6000000 \mathrm{~N} / \mathrm{m} \\
& F_{10}=650 \mathrm{~N} \\
& F_{20}=350 \mathrm{~N} \\
& L_{1 \mathrm{lim}}^{\prime}=0.034 \mathrm{~m}
\end{aligned}
$$

$$
\begin{aligned}
& L_{1 \lim }^{\prime \prime}=0.003 \mathrm{~m} \\
& L_{2 \lim }=0.05 \mathrm{~m} \\
& k_{h d}=6000 \mathrm{Ns} / \mathrm{m} \\
& F_{f r}=1000 \mathrm{~N}
\end{aligned}
$$

$$
\begin{aligned}
& \text { 30mm weapon } \\
& f_{\text {press }}=25 \mathrm{~Hz} \\
& F_{\text {press } \max }=220000 \mathrm{~N} \\
& k_{1}=6000000 \mathrm{~N} / \mathrm{m} \\
& M_{1}=35 \mathrm{~kg} \\
& k_{2}=750000 \mathrm{~N} / \mathrm{m} \\
& M_{2}=110 \mathrm{~kg} \\
& k_{\text {buf }}=4000000 \mathrm{~N} / \mathrm{m} \\
& k_{s t}=20000000 \mathrm{~N} / \mathrm{m} \\
& F_{10}=2800 \mathrm{~N} \\
& F_{20}=3000 \mathrm{~N} \\
& L_{1 \lim }^{\prime}=0.096 \mathrm{~m} \\
& L_{1 \mathrm{lim}}^{\prime \prime}=0.002 \mathrm{~m} \\
& L_{2 \lim }=0.1 \mathrm{~m} \\
& \mathrm{k}_{\mathrm{hd}}=7500 \mathrm{Ns} / \mathrm{m} \\
& \mathrm{F}_{\mathrm{fr}}=5000 \mathrm{~N}
\end{aligned}
$$

\section{References}

[1] АЛФЕРОВ,В.В.: Конструкиия и расчет автоматического оружия, Машиностроение, 1977, Москва.

[2] TONDL,A.:Автоколебания механических систем, Мир, 1979, Москва (translation).

[3] JANDRIĆ, M.: "PARTNER 2011" Weaponry and military equipment fair, Scientific Technical Review, ISSN 1820-0206, 2011, Vol.61, No.2, pp.61-69.

[4] JANDRIĆ, M.: Seventh Decade of the Military Technical Institute (1948.-2013.), Scientific Technical Review, ISSN 1820-0206, 2013, Vol.63, No.2, pp.5-25.

[5] WWW.yugoimport.com.

[6] JOVANOVIĆ,S, BANJAC,Z.: Development testing of vibrations on the helicopter with automatic weapon, $4^{\text {th }}$ International Conference NOISE AND VIBRATION, 17-19. October 2012, Niš, SERBIA, Proceedings, ISBN 978-86-6093-042-4, pp.159-165.

\title{
Mehanički oscilatorni sistem sa dva stepena slobode kretanja, sa pobudom i ograničenjima kretanja - slučaj automatskog oružja
}

\begin{abstract}
U ovom radu je data numerička analiza dinamike kretanja pravolinijskog oscilatornog sistema sa dva stepena slobode kretanja, sa prinudnom pobudom i ograničenjima kretanja. Analiza mehaničko-matematičkog modela sa prekidnim parametrima je bazirana na numeričkoj integraciji diferencijalnih jednačina. Prinudni oscilatorni sistem je realizovan kroz dva sistema automatskog oružja kalibra $12.7 \mathrm{~mm}$ i $20 \mathrm{~mm}$, ugrađena u laki elisni avion, odnosno transportno-borbeni helikopter. Izvršena su merenja parametara kretanja, a to su pomeranje i brzina, kao i sila na probnom postolju. Računske vrednosti parametara kretanja i sila su u saglasnosti sa analognim izmerenim vrednostima na realizovanim sistemima. Mehaničko-matematički model dinamike sistema se može koristiti za predikciju ponašanja sistema sa dva stepena slobode kretanja u fazi usklađivanja parametara, pre konstruisanja elemenata sistema. Dat je opis merenja i korištene opreme i predlog daljeg rada.
\end{abstract}

Ključne reči: mehanički sistem, oscilatorni sistem, oscilatorno kretanje, sopstvene oscilacije, sopstvena učestanost, pobuđivanje sistema, prinudne oscilacije, prigušenje oscilacija, automatsko oružje, kalibar 12.7 mm, kalibar 20 mm, naoružanje letelice. 


\title{
Механическая колебательная система с двумя степенями свободы движения, с возбуждением и ограничениями движения - в случае автоматического оружия
}

\begin{abstract}
В данной работе даётся численный анализ динамики движения прямолинейной колебательной системы с двумя степенями свободы передвижения, со принудительным возбуждением и ограничением движения. Анализ механикоматематической модели с прерывистыми параметрами проводится на основе численного интегрирования дифференциальных уравнений. Принудительная колебательная система реализуется с помощью двух систем автоматического оружия калибров 12,7 мм и 20 мм, встроенных в лёгком винтовом самолёте, а также в транспортнобоевом вертолёте. Мы выполнили измерения параметров движения, таких как перемещения и скорости, а также и силы на испытательном стенде. Расчётные значения параметров движения и силы являются в соответствии с аналоговыми измерениями на внедренных системах. Механико-математическая модель динамики системы может быть использована для прогнозирования поведения системы с двумя степенями свободы движения в фазе выравнивания параметров до проектирования элементов системы. Здесь описаны измерения и использованное измерительное оборудование, а в том числе и предложение о дальнейшей работе.
\end{abstract}

Ключевые слова: механическая система, колебательная система, колебательное движение, собственные колебания, возбуждение системы, вынужденные колебания, затухание колебаний, автоматическое оружие, калибр 12,7 мм, калибр 20 мм, вооружение летающего аппарата.

\section{Le système mécanique oscillatoire à deux degrés de liberté de mouvement avec l'excitation et les limitations du mouvement - cas d'armement automatique}

\begin{abstract}
Dans ce travail on a présenté l'analyse numérique de la dynamique de mouvement du système oscillatoire rectiligne à deux degrés de liberté de mouvement avec l'excitation forcée et la limitation du mouvement. L'analyse du modèle mécanique mathématique avec les paramètres discontinus est basée sur l'intégration numérique des équations différentielles. Le système oscillatoire a été réalisé au moyen de deux systèmes d'arme automatique de calibre de $12,7 \mathrm{~mm}$ et $20 \mathrm{~mm}$ installés à bord d'un avion léger à hélice ainsi qu'à bord d'un hélicoptère de transport et de combat. On a mesuré les paramètres de mouvement et de vélocité ainsi que la force sur stand. Les valeurs de ces paramètres sont en accord avec les valeurs analogiques mesurées sur les systèmes réalisés. Le modèle mécanique mathématique de la dynamique du système peut s'utiliser pour la prédiction du comportement du système à deux degrés de liberté de mouvement dans la phase de l'ajustement des paramètres avant la construction des éléments de système. On a présenté aussi la description de mesurage et l'équipement utilisé ainsi que la proposition pour les futurs travaux.
\end{abstract}

Mots clés: système mécanique, système oscillatoire, mouvement oscillatoire, oscillations propres, excitation du système, oscillations forcées, étouffement des oscillations, analyse numérique, arme automatique, calibre 12,7, calibre 20, armement de l'aéronef. 